\title{
EFFECT OF SIX WOOD EXTRACTS FROM FAMILY MELIACEAE AGAINST Psammotermes hybostoma (DESNEUX) (ISOPTERA: RHIMOTERMITIDAE). B - EFFECT OF SPRING WOOD EXTRACTS \\ Sayed, R. M. M. ${ }^{\star}$ and Hoda. M. Abdel Wahab** \\ ${ }^{*}$ Forestry Dept..Hort. Res. Ins. Agric. Res. Centre, Giza. \\ **Zoology Dept., Fac. of Sciences, Aswan Univ.
}

\begin{abstract}
This study was carried out to study the toxic effects of different wood spring extracts from certain woody trees belong to Family Meliaceae in spring against Psammotermes hybostoma at the Tropical Farm, Aswan Botanical Garden and Fac. of Science, Aswan Univ. during 2011 and 2012 seasons. The meliaceous trees chosen were Khaya senegalensis, K. ivorensis, Swietenia mahagoni, S. macrophylla, Azedarachta indica and Melia azedarach. Summarized results revealed that, $S$. mahagoni followed by $K$. ivorensis produced the highest values of total extracts while, $M$. azedarach and $S$. macrophylla produced the lowest values in the two seasons. Using water as a solvent produced the highest values of all wood extracts compared to the other solvents. Moreover, increasing concentrations up to $400 \mathrm{mg} / \mathrm{l}$ of the different spring wood extracts resulted in gradual increases in mortality percentage for the $3^{\text {rd }}$ instars of termite. Using $350 \mathrm{ppm}$ of either $M$. azedarach or K. ivorensis alcohol + benzene extracts caused the highest values of mortality percentage for $P$. hybostoma. On the other hand, spring wood extract by benzene alone from either $M$. azedarach or $K$. senegalensis at $350 \mathrm{ppm}$ resulted in the most effective treatments on termite compared to the other treatments. According to LC 90 (350 ppm) values, results revealed that either alcohol + benzene extract or benzene extract alone of the tested trees was highly toxic to $P$. hybostoma $3^{\text {rd }}$ instars worker. Meanwhile, according to LC 50 values using the lowest concentrations (75 and $100 \mathrm{ppm}$ ) of alcohol + benzene extract for $M$. azaderach and $S$. macrophylla, respectively led to toxic effect on $P$. hybostoma equal to the toxicity of other trees at the highest concentration.
\end{abstract}

\section{INTRODUCTION}

Mahogany common name for the Meliaceae, a widely distributed family of chiefly tropical shrubs and trees. In Egypt, most species of this family grow very well throughout the Republic and to be more superior in growth in Upper Egypt. The valuable hardwood called mahogany is obtained from many members of the family and vary in color from golden to deep brown, which produced a valuable wood for carpentry, joinery, furniture, cabinet work, ship building, decorative veneer, decorative boxes and cases. And is also commonly used for window frames, paneling, doors and staircases. It is suitable for light construction, light flooring, vehicle bodies, handles, sporting goods, musical instruments, pulpwood and most of all as pesticides. However, the six successful woody trees are Khaya senegalensis, $K$. ivorensis, Swietenia mahagoni, S. macrophylla, Azadirachta indica and Melia azedarach which belong to family Meliaceae. These valuable trees contain 
certain components which have some biological activity as insect's antifeedant (Nakatani et al., 2000) against several insects.

Extracts are the compounds present in trees that can be extracted by organic solvents. They are found in higher concentrations in the bark and wood of most timber trees and are generally considered to be biosynthesized in order to slow or prevent pathogen invasion. Their production is under strict genetic control, and some individual compounds are limited to individual species. Such compounds such as these are broadly classified as secondary metabolites. The biological value of these secondary metabolites is due to the presence of chemical substances that produce a definite physiological action. The most important of these include: alkaloids, glycosides, steroids, flavanoids, fatty acids, phenols, resins, phosphorus and calcium for cell growth, replacement, and body building (Chidambara. et al., 2003). Moreover, green plants posses the broadest spectrum of synthetic activity and have been the source of many useful compounds (Sofowora, 1986). Coincidentally, the last decade has also witnessed increasing intensive studies on extracts and biologically active compounds isolated from plant species used for natural therapies or herbal medicine (Rıos and Recio, 2005).

Subterranean termites are the most destroyers in arid and semi- arid ecosystems (Krishmo, 1989). The sand termite, Psammotermes hybostoma (Desneux) considered a serious pest in Aswan Province (Rizk et al., 1982, Abdel Wahab and Rizk, 1998 and Abdel Wahab et al., 1998). Termites mostly feed on dead plant material, generally in the form of wood, leaf litter, soil or animal dung, and many species of termites are economically significant as pests that can cause serious structural damage to buildings, crops or plantation forests (Shaalan et al., 2006). The various effects of the extracts on these insects included, attractively, repellence, toxicity, stimulation or inhibition of feeding and growth (Carter, 1976 and Hanif et al., 1988). Therefore, this study was designed to examine the effects of spring wood extracts of some Meliaceae trees against Psammotermes hybostoma (Desneux).

\section{MATERIALS AND METHODS}

This study was carried out at the Tropical Farm, Kom- Ombo, Aswan Botanical Garden, Hort. Res. Inst., Agric. Res. Center and Zoology Dept., Fac. of Science Aswan Univ. during the seasons of 2011 and 2012 to study the effect of wood extracts of some tree species on Psammotermes hybostoma termite.

\section{Botanical extracts:}

\section{Wood species:}

Six wood tree species i.e., Khaya senegalensis, K. ivorensis, Swietenia mahagoni, S. macrophylla, Azadirachta indica, and Melia azaderach at age of 15 years were investigated in the present study. 


\section{Extraction technique:}

Wood samples from the main branches (at least $10 \mathrm{~cm}$ in diameter) in the spring (15 th April) were dried at $70^{\circ} \mathrm{C}$ and milled then ground with 40-60 mech. Three solvent were used i.e., ethyl alcohol + benzene (1:2 by volume) for $4 \mathrm{~h}$., wood residue were air dried then extracted by benzene for $4 \mathrm{~h}$., as wood residue were air dried then extracted by water for $4 \mathrm{~h}$. according to ASTM D- 1107 - 56 (1989). Wood samples were weighed before and after each extraction then each was calculated as percentage of wood in both seasons.

Termite species: Psammotermes hybostoma termite was used in the present study. These termites are abundant in arid and semi- arid regions of Upper Egypt, and the highly infested places are these of high moisture content.

Collection and preparation for tests: $P$. hybostoma individuals were collected from several cardboard baits buried in the Saddaka, El- Shallal district, Aswan Province, Egypt. The termite colony was kept in a large plastic container for three months. The container was filled with corsage cardboard as termite feeding. One day prior to test termite workers as externally undifferentiated insects beyond the $3^{\text {rd }}$ instars were counted (50 individuals) and transferred to the test plastic container and starved for $24 \mathrm{~h}$. before the test.

\section{1-Bioassay:}

Preliminary screening and toxicological tests: For testing termite workers in both preliminary and LC 50 investigations, a stock solution of crude extract was prepared at $1 \mathrm{gm}$ in $10 \mathrm{ml}$ of absolute ethyl alcohol $(100.000 \mathrm{ml} / \mathrm{l})$ and required concentrations were prepared in ethyl alcohol for preliminary screening and toxicological tests. Crude extracts were screened at descending series of concentrations $(10,50,100,200,300$ and $400 \mathrm{mg} / \mathrm{L})$ to determine the LC30, LC 50 and LC90. In addition control (ethyl alcohol + benzene, benzene and water).

Extracts that caused $100 \%$ mortality at $200 \mathrm{ppm}$ were only selected and permitted for testing at the next concentration and so on. Termite workers were subjected to different concentrations (at least five concentrations) of crude botanical extracts (paper pads treated with each conc.) fixed in plastic containers to determine LC 50 . About 50 healthy workers beyond the $3^{\text {rd }}$ instars were starved for $24 \mathrm{~h}$. before testing and released into plastic containers containing $50 \mathrm{gm}$ sterile sand and $1 \mathrm{ml}$ distilled water. Containers were incubated at room temperature and mortality percent was recorded after $24 \mathrm{~h}$. Abbott's formula (1925) which was used to correct mortality percentage if the control mortality percent was between 5 and $20 \%$.

\section{2-Statistical analysis:}

Data analysis was performed using ANOVA according to the method of Snedecor (1965), and L.S.D. mentioned by Little and Hills (1978). The probate analysis statistical method and Litchified and Wilcoxon (1949) was used to calculate the logarithmic concentration probate line (LC- P lines) and the medium lethal concentration (LC 50), also the high lethal concentration (LC 90) values for each tested extract. 


\section{RESULTES}

\section{1 - Wood extracts:}

Data shown in Table (1) illustrate the mean values of spring wood extract percentages of 2011 and 2012 for the tested meliaceous trees as affected by alcohol and benzene, benzene and water as solvents. This study has shown that, there were differences between the wood extract percentages of this trees and the highest content of total extracts in wood can be obtained by $S$. mahogany followed by $K$. ivorensis while, the lowest one can be obtained with $M$. azaderach in the two seasons. Also, there were significantly differences between the solvents used and_the values of wood extract percentages for the studied trees were increased due to using water as a solvent compared to the other applied solvents. Meanwhile, using benzene alone as a solvent resulted in the lowest values of wood extract percentage in the two seasons.

Table (1) : Wood extracts percentage for six species of Family Meliaceae in the two seasons of 2011 and 2012.

\begin{tabular}{|c|c|c|c|c|c|c|c|c|}
\hline \multirow{3}{*}{ Species } & \multicolumn{8}{|c|}{ Wood extract $\%$ by 3 different solvents } \\
\hline & \multicolumn{4}{|c|}{ First season (2011) } & \multicolumn{4}{|c|}{\begin{tabular}{|l|} 
Second season (2012) \\
\end{tabular}} \\
\hline & \begin{tabular}{|c|}
$\begin{array}{c}\text { Alcohol \& } \\
\text { benzene }\end{array}$ \\
\end{tabular} & Benzene & Water & $\begin{array}{c}\text { Total } \\
\text { extract }\end{array}$ & $\begin{array}{l}\text { Alcohol \& } \\
\text { benzene }\end{array}$ & Benzene & Water & $\begin{array}{c}\text { Total } \\
\text { extracts }\end{array}$ \\
\hline \begin{tabular}{|l|} 
Khaya \\
senegalensis
\end{tabular} & 1.08 & 0.16 & 2.98 & 4.22 & 1.16 & 0.17 & 3.12 & 4.45 \\
\hline $\begin{array}{l}\text { Khaya } \\
\text { ivorensis }\end{array}$ & 0.96 & 0.14 & 3.50 & 4.59 & 1.02 & 0.16 & 3.65 & 4.82 \\
\hline \begin{tabular}{|l|} 
Azadirachta \\
indica
\end{tabular} & 1.04 & 0.26 & 1.78 & 3.08 & 1.13 & 0.28 & 1.89 & 3.30 \\
\hline $\begin{array}{l}\begin{array}{l}\text { Melia } \\
\text { azaderach }\end{array} \\
\end{array}$ & 1.20 & 0.25 & 1.48 & 2.93 & 1.29 & 0.27 & 1.57 & 3.13 \\
\hline \begin{tabular}{|l|}
$\begin{array}{l}\text { Swietenia } \\
\text { mahagoni }\end{array}$ \\
\end{tabular} & 1.41 & 0.19 & 2.99 & 4.59 & 1.52 & 0.21 & 3.20 & 4.92 \\
\hline \begin{tabular}{|l|} 
Swietenia \\
macrophylla
\end{tabular} & 0.94 & 0.21 & 1.79 & 2.94 & 1.01 & 0.22 & 1.90 & 3.14 \\
\hline $\begin{array}{l}\text { L.S.D. at } 1 \% \\
\text { at } 5 \%\end{array}$ & $\begin{array}{l}0.23 \\
0.16\end{array}$ & $\begin{array}{l}\text { N.S. } \\
\text { N.S. }\end{array}$ & $\begin{array}{l}0.51 \\
0.36\end{array}$ & $\begin{array}{l}0.66 \\
0.46\end{array}$ & $\begin{array}{l}0.23 \\
0.16\end{array}$ & $\begin{array}{l}\text { N.S } \\
\text { N.S. }\end{array}$ & $\begin{array}{l}0.49 \\
0.35\end{array}$ & $\begin{array}{l}0.66 \\
0.46\end{array}$ \\
\hline
\end{tabular}

\section{2 - Preliminary screening of the wood extracts in winter against $P$. hybostoma:}

Data in Table (2) show the preliminary screening of different crude wood extract against $3^{\text {rd }}$ instars of $P$. hybostoma in spring of the two seasons. Data indicated that, increasing concentrations of the different crude wood extracts up to $400 \mathrm{mg} / \mathrm{l}$ resulted in gradual increases of mortality percentage for the $3^{\text {rd }}$ instars of termite. However, 10 and $50 \mathrm{mg} / \mathrm{l}$ concentrations were the lowest effective for all the tree species, while 300 and $400 \mathrm{mg} / \mathrm{l}$ were the most effective treatments in compared to the other treatments. Using $300 \mathrm{mg} / \mathrm{l}$ of alcohol + benzene extract from $K$. senegalensis, K. ivorensis, A. indica and $M$. azaderach resulted in the highest values of mortality percentages for termite compared to benzene extract alone. Meanwhile, $300 \mathrm{mg} / \mathrm{l}$ of benzene alone for S. mahagoni and S. macrophylla resulted in the best results. $S$. 
macrophylla followed by $M$. azaderach extracts were the most effective treatments compared to the other tree species on the $3^{\text {rd }}$ instars of $P$. hybostoma.

Table (2) : Preliminary screening of different crude wood extracts in spring against $3^{\text {rd }}$ instars individuals of Psammoterms hybostoma (24 hr).

\begin{tabular}{|c|c|c|c|c|c|c|c|}
\hline \multirow{2}{*}{\multicolumn{2}{|c|}{ Wood extracts in spring }} & \multicolumn{6}{|c|}{ Mortality ( \%) at concentration mg/ I } \\
\hline & & \multirow{2}{*}{$\begin{array}{c}10 \\
0\end{array}$} & \multirow{2}{*}{$\begin{array}{l}50 \\
12 \\
\end{array}$} & \multirow{2}{*}{$\begin{array}{c}100 \\
22 \\
\end{array}$} & \multirow{2}{*}{$\begin{array}{c}200 \\
55\end{array}$} & \multirow{2}{*}{$\begin{array}{c}300 \\
78 \\
\end{array}$} & \multirow{2}{*}{$\begin{array}{l}400 \\
100\end{array}$} \\
\hline Khava Seneralencic & Alcohol\&benzene & & & & & & \\
\hline кnaya senegalensis & Benzene & 0 & 8 & 18 & 32 & 61 & 100 \\
\hline \multirow{2}{*}{ Khaya ivorensis } & Alcohol\&benzene & 4 & 11 & 23 & 35 & 82 & 100 \\
\hline & Benzene & 0 & 13 & 15 & 38 & 81 & 100 \\
\hline \multirow{2}{*}{ Azadirachta indica } & Alcohol\&benzene & 1 & 14 & 24 & 41 & 63 & 100 \\
\hline & Benzene & 0 & 5 & 17 & 44 & 55 & 100 \\
\hline \multirow{2}{*}{ Melia azaderach } & Alcohol\&benzene & 1 & 2 & 71 & 88 & 91 & 100 \\
\hline & Benzene & 1 & 1 & 22 & 87 & 90 & 100 \\
\hline \multirow{2}{*}{ Swietenia mahagoni } & Alcohol\&benzene & 0 & 4 & 32 & 28 & 41 & 100 \\
\hline & Benzene & 1 & 2 & 11 & 61 & 78 & 100 \\
\hline \multirow{2}{*}{$\begin{array}{l}\text { Swietenia } \\
\text { macrophylla }\end{array}$} & Alcohol\&benzene & 0 & 15 & 41 & 91 & 92 & 100 \\
\hline & Benzene & 0 & 8 & 32 & 92 & 93 & 100 \\
\hline \multirow{3}{*}{ Control } & Alcohol\&benzene & 1 & 0 & 1 & 9 & 14 & 13 \\
\hline & Benzene & 1 & 0 & 1 & 7 & 12 & 13 \\
\hline & Water & 0 & 0 & 0 & 0 & 0 & 0 \\
\hline
\end{tabular}

3 - Toxicity of spring wood extract by alcohol and benzene:

Data of toxicity and mortality percentage of spring wood extract by alcohol and benzene tested against $3^{\text {rd }}$ instars of $P$. hybostoma were presented in Table (3). However, the tested trees were significantly differed in their toxicity and mortality percentage.

Table (3): Toxicity and mortality percentage of spring wood extract by alcohol \& benzene against $3^{\text {rd }}$ instar of Psammoterms hybostoma.

\begin{tabular}{|c|c|c|c|c|c|c|c|}
\hline \multirow{2}{*}{ Wood extracts } & \multicolumn{7}{|c|}{ Concentration ( ppm ) } \\
\hline & 100 & 150 & 200 & 250 & 300 & 350 & Mean (A) \\
\hline Khaya senegalensis & 9.25 & 16.75 & 24.50 & 36.50 & 65.00 & 81.50 & 38.92 \\
\hline Khaya ivorensis & 24.00 & 32.75 & 53.25 & 61.25 & 93.25 & 95.25 & 59.96 \\
\hline Azadirachta indica & 18.75 & 29.00 & 37.75 & 44.25 & 53.50 & 92.50 & 45.96 \\
\hline Melia azaderach & 52.75 & 70.00 & 75.75 & 83.25 & 93.25 & 99.25 & 79.04 \\
\hline Swietenia mahagoni & 24.00 & 34.00 & 45.25 & 62.50 & 72.75 & 91.50 & 55.00 \\
\hline $\begin{array}{l}\text { Swietenia } \\
\text { macrophylla }\end{array}$ & 25.25 & 42.25 & 64.00 & 70.25 & 78.50 & 87.00 & 61.21 \\
\hline Mean (B) & 25.67 & 37.46 & 50.08 & 59.67 & 76.04 & 91.17 & \\
\hline $\begin{array}{r}\text { LSD at } 1 \% \\
\text { at } 5 \%\end{array}$ & $\begin{array}{l}A: 11.93 \\
A: 8.62\end{array}$ & & & $\begin{array}{l}\mathrm{AB}: 12 . \\
\mathrm{AB}: 4.9\end{array}$ & & & \\
\hline
\end{tabular}

The highest mortality percentage was recorded with $M$. azaderach followed by $S$. macrophylla while, using $K$. senegalensis extracts resulted in the lowest one. On the other hand, toxicity and mortality percentage were significantly affected by the used concentrations. The increasing in concentrations up to 
$350 \mathrm{ppm}$ resulted in gradual increases in mortality percentage. In relation to the interaction between the used woody trees and extract concentrations, it is evident that, using $350 \mathrm{ppm}$ of $M$. azaderach and $K$. ivorensis caused the highest values of mortality percentage when compared to the other treatments.

\section{4 - Toxicity spring wood extracts by benzene :}

Data presented in Table (4) pointed out that there were significant increases in mortality percentage for $P$. hybostoma instars due to applying the different woody extract treatments. The highest value of mortality percentage $(62.67 \%)$ resulted from using $S$. macrophylla extract against $3^{\text {rd }}$ instars of $P$. hybostoma. Concerning the general effect of the tested concentrations on the $3^{\text {rd }}$ instars of $P$. hybostoma regardless of tree species, it is obvious that, the differences between concentrations effect were significant. The highest value $(88.79 \%)$ of mortality percentage resulted from using $350 \mathrm{ppm}$ and the lowest one (26.33\%) was with $100 \mathrm{ppm}$. In regard to the interaction between tree species and the used concentrations on mortality percent of $P$. hybostoma, it was significant and the maximum mortality $(92.25 \%)$ was recorded for $350 \mathrm{ppm}$ of $K$. senegalensis or $M$. azaderach, while the lowest mortality was recorded with $100 \mathrm{ppm}$ of $K$. ivorensis.

Table (4): Toxicity and mortality percentage of spring wood extract by benzene against $3^{\text {rd }}$ instars of Psammoterms hybostoma.

\begin{tabular}{|l|c|c|c|c|c|c|c|}
\hline \multirow{2}{*}{ Wood extracts } & \multicolumn{7}{|c|}{ Concentration ( ppm ) } \\
\cline { 2 - 8 } & 100 & 150 & 200 & 250 & 300 & 350 & Mean(A) \\
\hline Khaya senegalensis & 18.50 & 21.00 & 25.75 & 41.50 & 49.00 & 92.25 & 41.33 \\
\hline Khaya ivorensis & 15.00 & 27.50 & 42.50 & 48.50 & 79.00 & 91.75 & 50.71 \\
\hline Azadirachta indica & 35.00 & 38.50 & 44.00 & 53.75 & 66.75 & 78.00 & 52.67 \\
\hline Melia azaderach & 21.75 & 37.50 & 50.75 & 62.75 & 77.25 & 92.25 & 57.04 \\
\hline Swietenia mahagoni & 30.25 & 40.50 & 45.50 & 58.75 & 70.50 & 91.00 & 56.08 \\
\hline Swietenia macrophylla & 37.50 & 46.50 & 56.00 & 69.00 & 79.50 & 87.50 & 62.67 \\
\hline Mean (B) & 26.33 & 35.25 & 44.08 & 55.71 & 70.33 & 88.79 & \\
\hline $\begin{array}{l}\text { LSD at 1\% } \\
\text { at 5\% }\end{array}$ & A : N.S : 4.28 AB :10.49 & AB :4.33 & & \\
\hline
\end{tabular}

\section{5 - Toxicity of spring wood extract by water:}

Results of mortality percentages for the $3^{\text {rd }}$ instars of $P$. hybostoma as affected by spring wood water extracts are shown in Table (5). The tested meliaceous trees up to $150 \mathrm{ppm}$ were not effect. Using water as solvent for $K$. senegalensis and $M$. azaderach extract resulted in the highest values of mortality percentage for $P$. hybostoma compared to the other trees. Meanwhile, the lowest values of mortality resulted due to using water extract of S. macrophylla and A. indica. According to data, application of $350 \mathrm{ppm}$ gave the highest value of mortality compared to the other concentrations. On the other hand, the combined effect of wood extract and the used concentrations show that the highest value $(28 \%)$ of mortality percentage was due to M. azaderach with $350 \mathrm{ppm}$. 
Table (5): Preliminary screening of water wood extracts in spring against $3^{\text {rd }}$ instars individuals of Psammoterms hybostoma (24 hr).

\begin{tabular}{|l|c|c|c|c|c|c|c|c|}
\hline \multirow{2}{*}{ Water wood extracts } & \multicolumn{7}{|c|}{ Mortality (\%) at concentration (ppm) } \\
\cline { 2 - 10 } & 10 & 50 & 100 & 150 & 200 & 250 & 300 & 350 \\
\hline Khaya Senegalensis & 0 & 0 & 0 & 0 & 6 & 12 & 24 & 25 \\
\hline Khaya ivorensis & 0 & 0 & 0 & 0 & 10 & 12 & 13 & 18 \\
\hline Azadirachta indica & 0 & 0 & 0 & 0 & 3 & 6 & 9 & 14 \\
\hline Melia azaderach & 0 & 0 & 0 & 0 & 1 & 2 & 17 & 28 \\
\hline Swietenia mahagoni & 0 & 0 & 0 & 0 & 1 & 9 & 11 & 15 \\
\hline $\begin{array}{l}\text { Swietenia } \\
\text { macrophylla }\end{array}$ & 0 & 0 & 0 & 0 & 5 & 8 & 9 & 12 \\
\hline Control & 0 & 0 & 0 & 0 & 0 & 0 & 1 & 5 \\
\hline
\end{tabular}

Toxicity and mortality of spring wood water extracts against the $3^{\text {rd }}$ instars of $P$. hybostoma are presented in Table (6). It is worthy to notice that the differences between meliaceous trees were not significant. Maximum mortality $(31.21 \%)$ was obtained due to using $K$. senegalensis extract. On the other hand, the differences between the concentrations used were significant and using $800 \mathrm{ppm}$ of water extract resulted in the highest value of toxicity $(44.29 \%)$ compared to the other concentrations. However, data in this table represented the combined effect of the woody extract and the tested concentrations; it was obvious that there were significant differences between water extracts and their concentrations and maximum mortality $(49.00 \%)$ was recorded by using $800 \mathrm{ppm}$ of either $K$. senegalensis or $K$. ivorensis.

Table (6): Toxicity and mortality percentage of spring wood extract by water tested against $3^{\text {rd }}$ instars of Psammotermes hybostoma.

\begin{tabular}{|l|c|c|c|c|c|c|c|}
\hline \multirow{2}{*}{ Wood extracts } & \multicolumn{7}{|c|}{ Concentration (ppm ) } \\
\cline { 2 - 9 } & 300 & 400 & 500 & 600 & 700 & 800 & Mean(A) \\
\hline Khaya senegalensis & 13.25 & 20.25 & 26.75 & 34.50 & 43.50 & 49.00 & 31.21 \\
\hline Khaya ivorensis & 5.75 & 15.50 & 26.00 & 36.00 & 44.00 & 49.00 & 29.38 \\
\hline Azadirachta indica & 6.00 & 16.75 & 20.50 & 26.50 & 34.75 & 42.50 & 24.50 \\
\hline Melia azaderach & 15.25 & 27.50 & 29.75 & 34.00 & 36.50 & 41.00 & 30.67 \\
\hline Swietenia mahagoni & 12.25 & 18.75 & 22.50 & 32.75 & 36.50 & 43.00 & 27.63 \\
\hline Swietenia macrophylla & 11.00 & 16.25 & 24.50 & 35.75 & 39.25 & 41.25 & 28.00 \\
\hline Mean (B) & 10.58 & 19.17 & 25.00 & 33.25 & 39.08 & 44.29 & \\
\hline LSD at 1\% & A : N.S & B : $: 53.53$ & AB :6.20 \\
at 5\% & A : N.S & B : $: 1.05$ & AB : $: 2.56$ \\
\hline
\end{tabular}

$A=$ Wood extracts $\quad B=$ Concentration (ppm ) $\quad A B=$ Interaction

\section{$6-\mathrm{LC}_{30}, \mathrm{LC}_{50}, \mathrm{LC}_{90}$ and slope data of spring wood - alcohol + benzene extracts:}

Data shown in Table (7) represented the values of LC 30, LC 50 and LC 90 and slope data of spring plant- alcohol + benzene tested against $3^{\text {rd }}$ instars larva of Psammotermes hybostoma. According to LC 90 values data showed that, K. senegalensis, K. ivorensis, A. indica, M. azaderach, S. mahagoni and $S$. macrophylla alcohol + benzene extract (350 ppm) was resulted in the same effect and highly toxic to $P$. hybostoma 3rd instars worker. The slope 
values of LC 90 in A. indica and S. mahagoni, alcohol + benzene extracts were closely similar $(0.11$ and 0.11$)$ while, the highest slope value $(0.25)$ was due to $M$. azedarach. According to LC 50 values, Table (7) showed that alcohol + benzene extract of $M$. azaderach and $S$. macrophylla trees were highly toxic against termite workers at 75 and $100 \mathrm{ppm}$, respectively. On the other hand, LC 30 values of the tested trees show that the lowest concentrations (50 and $75 \mathrm{ppm}$ ) of $M$. azaderach and $S$. macrophylla, respectively resulted in moderate toxic effect for $P$. hybostoma compared to the other tested trees.

Table (7) : $\mathrm{LC}_{30}, \mathrm{LC}_{50}, \mathrm{LC}_{90}$ and slope data of spring wood - alcohol + benzene extracts against $3^{\text {rd }}$ instars larva of Psammotermes hybostoma .

\begin{tabular}{|c|c|c|c|c|c|c|c|c|c|}
\hline \multirow{2}{*}{ Wood extracts } & \multicolumn{3}{|c|}{ L.C. 30} & \multicolumn{3}{|c|}{ L.C. 50} & \multicolumn{3}{|c|}{ L. C. 90} \\
\hline & p.p.m & $95 \%$ & Slop+S.E & p.p.m & $95 \%$ & Slop+S.E & p.p.m & $95 \%$ & Slop+S.E \\
\hline $\begin{array}{l}\text { Khaya } \\
\text { senegalensis }\end{array}$ & 200 & 30.59 & $\begin{array}{r}12.76 \\
+1.03 \\
\end{array}$ & 250 & 50.79 & \begin{tabular}{|r|}
17.38 \\
+1.92 \\
\end{tabular} & 350 & 90.00 & $\begin{array}{c}0.10 \\
+37889.07\end{array}$ \\
\hline $\begin{array}{l}\text { Khaya } \\
\text { ivorensis }\end{array}$ & 100 & 30.02 & $\begin{array}{c}9.23 \\
+0.60\end{array}$ & 150 & 50.01 & $\begin{array}{r}14.12 \\
+1.20 \\
\end{array}$ & 350 & 90.00 & $\begin{array}{c}0.13 \\
+44425.27\end{array}$ \\
\hline $\begin{array}{l}\text { Azadirachta } \\
\text { indica }\end{array}$ & 200 & 30.02 & $\begin{array}{r}18.68 \\
+3.15\end{array}$ & 250 & 50.00 & $\begin{array}{l}37.53 \\
+5.80\end{array}$ & 350 & 90.00 & $\begin{array}{c}0.11 \\
+40613.51\end{array}$ \\
\hline $\begin{array}{l}\text { Melia } \\
\text { azaderach }\end{array}$ & 50 & 30.31 & $\begin{array}{c}5.17 \\
+0.20\end{array}$ & 75 & 50.24 & $\begin{array}{r}6.26 \\
+0.38\end{array}$ & 350 & 90.00 & $\begin{array}{c}0.25 \\
+77799.37\end{array}$ \\
\hline \begin{tabular}{|l|} 
Swietenia \\
mahagoni
\end{tabular} & 100 & 30.03 & $\begin{array}{r}7.89 \\
+0.60\end{array}$ & 200 & 50.62 & $\begin{array}{l}12.91 \\
+1.33\end{array}$ & 350 & 90.00 & $\begin{array}{c}0.11 \\
+37144.23\end{array}$ \\
\hline $\begin{array}{l}\text { Swietenia } \\
\text { macrophylla }\end{array}$ & 75 & 30.47 & $\begin{array}{r}5.10 \\
+0.28\end{array}$ & 100 & 50.08 & $\begin{array}{r}6.65 \\
+0.56 \\
\end{array}$ & 350 & 90.00 & \begin{tabular}{|c|}
0.12 \\
+41083.99
\end{tabular} \\
\hline
\end{tabular}

\section{7 - LC $\mathbf{C}_{30}, \mathbf{L C}_{50}, \mathrm{LC}_{90}$ and slope data of spring plant - benzene extract:}

Data shown in Table (8) pointed out that, LC 50 values of the tested Meliaceous trees benzene extract in spring was highly toxic to termite (150 ppm for S. macrophylla and M. azaderach; $200 \mathrm{ppm}$ for A. indica, $S$.

mahagoni and $K$. ivorensis; $250 \mathrm{ppm}$ for $K$. senegalensis ). Also, LC 50 values of the trees were nearly similar (50.00). The highest slope values were obtained with $K$. ivorensis and S. mahagoni (16.70 and 14.41, respectively) while; the lowest value (0.03) was obtained with $K$. senegalensis. According to LC 90 values of the tested trees, tabulated data pointed out that benzene extract tested against 3rd larva of termite was highly toxic (350 ppm) and was similar (90.00). The slope values of $K$. ivorensis, A. indica and S. mahagoni were typical (0.11), also $M$. azaderach and $S$. macrophylla were typical slope values $(0.12)$. 
Table (8) : $\mathrm{LC}_{30}, \mathrm{LC}_{50}, \mathrm{LC}_{90}$ and slope data of spring wood - benzene extract against $3^{\text {rd }}$ instars larva of Psammotermes hybostoma .

\begin{tabular}{|c|c|c|c|c|c|c|c|c|c|}
\hline \multirow{2}{*}{ Wood extracts } & \multicolumn{3}{|c|}{ L.C. 30} & \multicolumn{3}{|c|}{ L.C. 50} & \multicolumn{3}{|c|}{ L. C. 90} \\
\hline & p.p.m & $95 \%$ & Slop \pm S.E & p.p.m & $95 \%$ & Slop \pm S.E & p.p.m & $95 \%$ & Slop \pm S.E \\
\hline $\begin{array}{l}\text { Khaya } \\
\text { senegalensis }\end{array}$ & 250 & 30.28 & $\begin{array}{c}24.41 \pm \\
2.54\end{array}$ & 250 & 50.27 & $\begin{array}{l}0.03 \pm \\
0.003\end{array}$ & 350 & 90.00 & $\begin{array}{c}0.07 \pm \\
34041.60\end{array}$ \\
\hline Khaya ivorensis & 150 & 30.21 & $\begin{array}{c}10.62+ \\
0.87\end{array}$ & 200 & 50.08 & $\begin{array}{c}16.70 \pm \\
1.49\end{array}$ & 350 & 90.00 & $\begin{array}{c}0.11 \pm \\
39999.80\end{array}$ \\
\hline $\begin{array}{l}\text { Azadirachta } \\
\text { indica }\end{array}$ & 100 & 30.76 & $\begin{array}{c}4.98 \pm \\
0.50\end{array}$ & 200 & 50.39 & $\begin{array}{c}10.73 \pm \\
1.52\end{array}$ & 350 & 90.00 & $\begin{array}{c}0.11 \pm \\
35444.75\end{array}$ \\
\hline Melia azaderach & 100 & 30.22 & $\begin{array}{c}6.92 \pm \\
0.48\end{array}$ & 150 & 50.02 & $\begin{array}{c}11.86 \pm \\
1.23\end{array}$ & 350 & 90.00 & $\begin{array}{c}0.12 \pm \\
39715.28\end{array}$ \\
\hline $\begin{array}{l}\text { Swietenia } \\
\text { mahagoni }\end{array}$ & 100 & 30.16 & $\begin{array}{c}6.78 \pm \\
0.60\end{array}$ & 200 & 50.20 & $\begin{array}{c}14.41 \pm \\
1.75\end{array}$ & 350 & 90.00 & $\begin{array}{c}0.11 \pm \\
39605.31\end{array}$ \\
\hline $\begin{array}{l}\text { Swietenia } \\
\text { macrophylla }\end{array}$ & 75 & 30.72 & $\begin{array}{c}4.78 \pm \\
0.29\end{array}$ & 150 & 50.95 & $\begin{array}{l}7.60 \pm \\
0.74\end{array}$ & 350 & 90.00 & $\begin{array}{c}0.12 \pm \\
37706.11\end{array}$ \\
\hline
\end{tabular}

\section{8 - $\mathrm{LC}_{30}$ and Slope data of spring wood - water extract:}

Data in Table (9) show LC30 and slope data of spring plant- water extract against termite. In this table, water extracts of the tested woody trees were approximately similar in their effect on $P$. hybostoma at $500 \mathrm{ppm}$. The slope values were different among the six tree species extracts and the highest value (14.12) was obtained with $A$. indica followed by $S$. mahagoni (9.34), while the lowest one (6.51) was with $M$. azaderach.

Table (9): $\mathrm{LC}_{30}$ and Slope data of spring wood - water extracts against $3^{\text {rd }}$ instars larva of Psammotermes hybostoma .

\begin{tabular}{|l|c|c|c|}
\hline \multicolumn{1}{|c|}{ Wood extracts } & \multicolumn{3}{c|}{ L.C. 30 } \\
\cline { 2 - 4 } & ppm & $95 \%$ & Slop \pm S.E \\
\hline Khaya senegalensis & 500 & 30.86 & $8.37 \pm 1.39$ \\
\hline Khaya ivorensis & 500 & 30.96 & $8.23 \pm 1.23$ \\
\hline Azadirachta indica & 600 & 30.27 & $14.12 \pm 4.35$ \\
\hline Melia azaderach & 500 & 30.74 & $6.51 \pm 1.85$ \\
\hline Swietenia mahagoni & 500 & 30.20 & $9.34 \pm 2.46$ \\
\hline Swietenia macrophylla & 500 & 30.64 & $7.20 \pm 1.42$ \\
\hline
\end{tabular}

\section{DISCUSSION}

Extracts contents are quite variable within individual species and are also site specific (i.e. the extractive content of two genetic clones of an individual species will vary depending on the site the trees are placed). Values also depend on method of extraction, time of extraction vs. date of felling, amount of heartwood, etc. Extracts of woody plants tend to be under-emphasized in classes devoted to wood chemistry basically because there is no real simple way to describe all the materials that can be formed. This is unfortunate because extracts are responsible for many useful and practical aspects of wood, and they can also be a severe detriment to wood and fiber processing. For example, many researchers revealed that, meliaceous trees contain certain components which have some biological activity as insect's 
antifeedant (Nakatani et al., 2000) against several insects. Moreover, this investigation confirmed the toxic effects of meliaceous trees as a botanical extracts on instars of $P$. hybostoma; there were differences in their effects as reported by Alfazairy et al. (1994); Badshah et al. (2004); Shaalan et al. (2006) and Olufemi et al. (2011). Also, mortality percentages due to the used wood extracts were significantly different from control, suggesting the toxic effect of this family against termites. Abdelgaleil et al. (2004) reported that $K$. senegalensis trees have many compounds as limonoids named seneganolide A, 2-hydroxyseneganolide A and 2- acetoxyseneganolide A. These limonoids have a wide range of biological activities, including insect antifeeding and growth-regulating properties, and medicinal activities in humans and animals. They also possess antiviral, antifungal and bactericidal properties (Abdelgaleil et al., 2001; Abdelgaleil and Nakatani, 2003; Ademola et al., 2004). The present study found that, S. mahagoni and K. ivorensis were superior in total spring wood extracts compared to the other trees. Moreover, toxicity and mortality percentage of spring wood extract by alcohol + benzene were superior to that of the other solvents except for $S$. mahagoni, in which benzene extract alone was the most effective. Data on toxicity in spring extract (alcohol + benzene) pointed out that $M$. azaderach followed by $S$. macrophylla were the most effective on termite compared to the other trees. On the other hand, data of spring wood extract by benzene alone stated that, $S$. macrophylla followed by $M$. azaderach were the best. However, compared to results of sublethal concentrations (LC 30, LC 50 and LC 90) of the tested extracts, organic solvent, were surprisingly better than water extract one. These results were in accordance with that of Alfazairy et al. (1994); Winks and Schimmer (1999) and Shaalan et al. (2006). Findings suggested that meliaceous wood extracts may produce larvicidal effects (behaving like general toxicants) against $P$. hybostoma. On the other hand, slope value for each of the tested extracts were quite different; which suggested the presence of different compounds and/ or sites of activity rather than differences in compound concentration.

\section{REFERENCES}

Abbott, W.S. (1925): Methods for computing the effectiveness of an insecticide. J. Econ. Entoml., 18 (2): 265- 273.

Abdelgaleil, S.A.M and M. Nakatani (2003): Antifeeding activity of limonoids from Khaya senegalensis. J. Appl. Entomol. 127: 236 - 239.

Abdelgaleil, S.A.M; H. Okamura; T. Iwagawa ; A. Sato ; I. Miyahara ; M. Doe and M. Nakatani (2001): Khayanolides rearranged phragmalin limonoid antifeedants from Khaya senegalensis. Tetrahedron, 57: 119 - 126.

Abdelgaleil,S.A.M; T. Iwagawa; M. Doe and M. Nakatani (2004): Antifungal limonoids from the fruits of Khaya senegalensis. Fitoterapia 77: 566 572.

Abdel Wahab, H.M. and M.A. Rizk (1998): The role of termites in destroying the wooden trees near Kima Factory, Aswan, Egypt. J. Egypt Ger. Soc. Zool., proc 8 the Int. Conf. 8- 11 Nov., 2000, 65- 77. 
Abdel Wahab, H.M.; A.I. Hamed and N.A. Emary (1998): Antitermite principles isolated from the wild herb, Psoralia plicata Del. Ass. Univ. Ball. Environ. Res., 1 (2): 17- 25.

Ademola I.O; B.O. Fagbemi and S.O. Idowu (2004): Evaluation of the antihelminthic activity of Khaya senegalensis extract against gastrointestinal nematodes of sheep: in vitro and in vivo studies. Vet. Parasitol, 122: 151 - 164 .

Alfazairy, A. A.; F.A. Hassan and A.M. Abd El- Dayem (1994): Insecticidal effect of three meliaceous seed oils against castes of the dry- wood termites, Kalotermis flavicollis Fabr. (Isoptera:Kalotermitidae). Proc the first conf. of Ornamental Hort. Vol. (2); 748- 762.

ASTM D- 1107- 56(American Society for Testing Materials (1989): Standard test methods for alcohol- benzene solubility of wood. ASTM D- 110756. Philadelphia, PA.

Badshah, H.; Z. Salihah; A. Salijogi and M. Shakur (2004): Toxic effects of AK (Calotropis procera) plant extracts against termis (Heterotermes indicola and Coptotermes heimi) Isoptera: Rhinotermitidae. Pakistan J. Biol. Sci., 7 (9): 1603- 1606.

Carter, F.L.(1976): Responses of subterranean termites to wood extractives. Material and Organismen Beiheft, 3: 357- 365.

Chidambara, K; A. Vanitha; M. Mahadeva and G.Ravishankar (2003): Antioxidant and antimicrobial activity of Cissus quandrangularis $L$. J. Med. Food, 6 (2): 183 - 190.

Hanif, G.; M.I. Ghadhury; M. Faroog and J. Rahmatullah (1988): Preliminary studies on antiermitic properties of common woods of Pakistan and their extracts. Pakistan J. of Forestry. 38: 167- 173.

Krishmo, K. (1989): Order Isoptera In: D.J.Borror; C.A.Triplehorn and N.F. Johnson (eds.) An Introduction to the Study of Insects. Saunders College Publishing, Philadeliphia, p. 234 - 241.

Litchfield, J.T. and F. Wilcoxon (1949): A simplified method of evaluating dose- effect experiments. J. Pharmac. Exp. Ther, 96: 99- 113.

Little, I. M. and F.J. Hills (1978): Agricultural Experimentation, Design and Analysis. Johan Wiely and Sons. Inc. New York.

Nakatani, M.; S.A.M. Abdelgaleil; H.Okamura; T.Iwagawa; A.Sato and M. Doe (2000): Khayanolides $A$ and $B$, new rearranged phragmalin limonoid antifeedants from Khaya senegalensis. Tetra. L.et., 41: (33), 6473- 6477.

Olufemi, A.S.; G.O. Yager; B.D. Zira and A. Usman (2011): Termiticidal effect of neem extracts on the wood of Khaya senegalensis. Research J. of Forestry, 5: 128- 138.

Rıos, J and M. Recio (2005): Medicinal plants and antimicrobial activity J. Ethnopharmacol., 100: 80-84.

Rizk, M.A.; F.M. Khalil and A. Maher Ali (1982): Assesment of damage due to termite in Egypt. 1. New Valley. Western desert. Assiut J. Agric. Sci., 13 (3): 93- 100. 
Shaalan, E.A.; D.V. Canyon; H. Abdel- Wahab and A. Mansour (2006): Efficacy of eight larvicidal botanical extracts from Khaya senegalensis and Daucus carota against Culex annulirostris. J. of AmericanMosquito Control Association, 22 (3). P: 433- 436.

Snedecor, G.W. (1965): Statistical Methods 5th ed. lowa State College Press, Ames, lowa.

Sofowora, A (1986): The State of Medicinal Plant Research in Nigeria. University of Ife Press Ife, Nigeria.

Winks, M. and O. Schimmer (1999): Modes of action of defensive secondary metabolities. Function of plant MSs and their exploitation in biotechnology. Annual Plant Reviews, Vol. 3, p. 17- 133.

$$
\begin{aligned}
& \text { تأثير مستخلصات ستة أنواع خثبية تابعة لعائلة الماهوجنى على النمل الأبيض }
\end{aligned}
$$

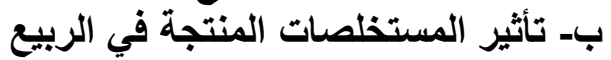

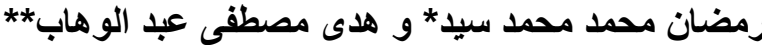

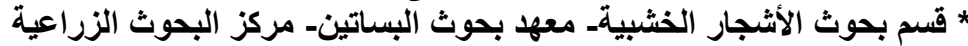

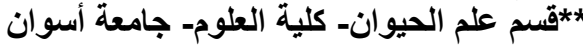

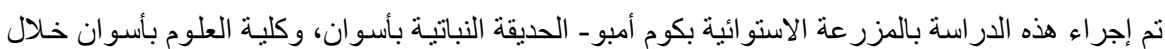

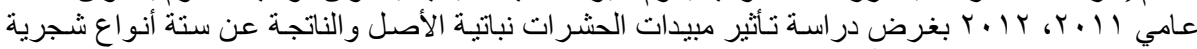

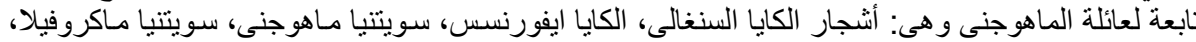

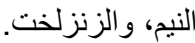

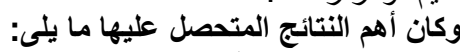

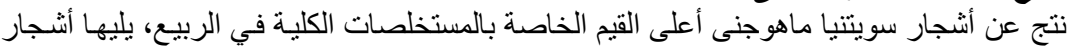

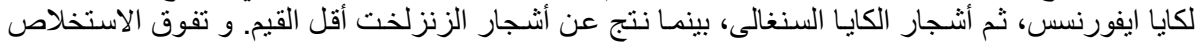

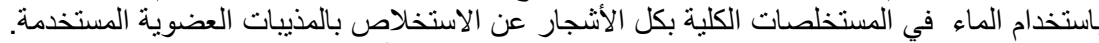

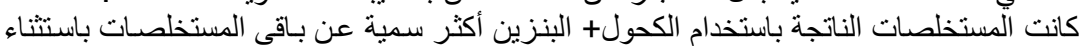

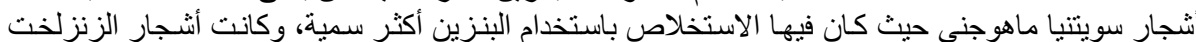

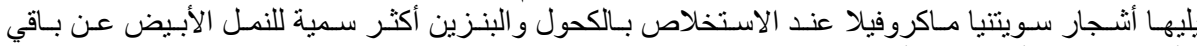
الأشجار، وكان أقلها سمية أشجار الكايا السنغالى.

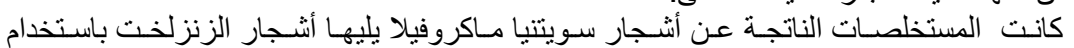

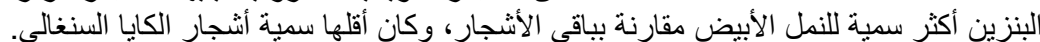

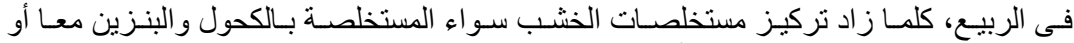

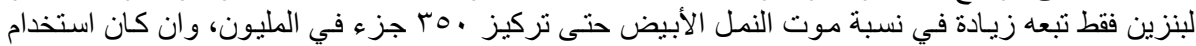

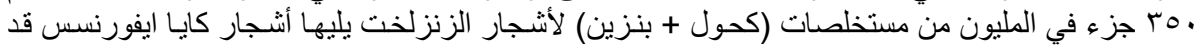

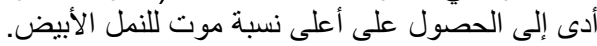

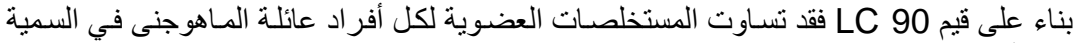

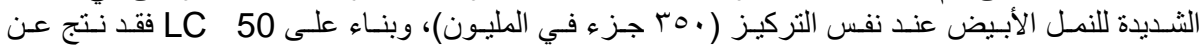

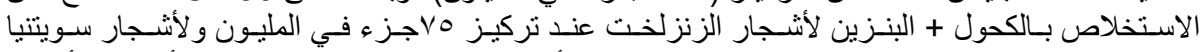

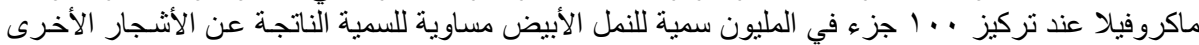

كلية الزراعة - جامعة المنصورة كلية الزراعة - جامعة كفر الثيخ الزعرة

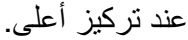
قام بتحكيم البحث اعلى

أ.د / حكمت يحى مسعود أ.د / أد / حمم محمد صابر نوفل 